\title{
Turkey meat quality (Meleagris gallopavo) submitted to different ventilation systems during fattening
}

\author{
Qualidade da carne de perus (Meleagris gallopavo) submetidos a diferentes sistemas de \\ ventilação durante a engorda
}

\author{
Diego Francisco MARCON ${ }^{1}$; Regiane Boaretto CRECENCIO ${ }^{1}$; Tanize Angonesi de CASTRO ${ }^{1}$; Leidiane Josi \\ BUDEL $^{1}$; Francisco Javier RAMIREZ-FERNANDEZ ${ }^{2}$; Karina Ramirez STARIKOFF ${ }^{1}$
}

\author{
${ }^{1}$ Universidade Federal da Fronteira Sul, Chapecó - SC, Brazil \\ ${ }^{2}$ Universidade de São Paulo, Escola Politécnica, São Paulo - SP, Brazil
}

\begin{abstract}
The present investigation evaluated the quality of turkey meat produced in two production systems, according to the following parameters: water loss in cooking, drip water loss, texture (shear strength), $\mathrm{pH}$, color, humidity, protein, ashes and lipids. A total of 200 turkey breast samples of $500 \mathrm{~g}$, separated by a batch of 20 samples, from ten aviaries from Santa Catarina, Brazil, were used: five from breeding with a traditional ventilation system and five with a mechanical ventilation system. Samples were obtained after slaughter and frozen at $-15^{\circ} \mathrm{C}$ for 30 days. The results were submitted to variance analysis and the Tukey test. Significant differences were found only in the analysis of drip water loss. The birds of the traditional ventilation system presented $14.26 \%$ loss of water drip, while those of the ventilation exhaust system presented a loss of $19.21 \%$. There were no differences in the chemical composition of poultry meat in relation to the production systems.
\end{abstract}

Keywords: Quality of turkey meat. Ventilation in the production of turkeys. Ventilation systems. Meleagris gallopavo.

\begin{abstract}
Resumo
O presente trabalho avaliou a qualidade da carne de perus criados em dois sistemas de produção, a partir dos seguintes parâmetros: perda de água na cocção, perda de água por gotejamento, textura (resistência ao cisalhamento), pH, cor, umidade, proteína, cinzas e lipídios. Foram utilizadas 200 amostras de peito de peru de $500 \mathrm{~g}$, separadas por lote de 20 amostras, de dez aviários de Santa Catarina, Brasil, dos quais: cinco provenientes de criação com sistema de ventilação tradicional e cinco com sistema de ventilação mecânica. As amostras foram obtidas após o abate e congeladas a $-15^{\circ} \mathrm{C}$ durante 30 dias. Os resultados foram submetidos à análise de variância e ao teste de Tukey. Diferenças significativas foram encontradas apenas na análise da perda de água por gotejamento. As aves do sistema de ventilação tradicional apresentaram 14,26\% de perda de gotejamento de água, enquanto as do sistema de exaustão de ventilação, 19,21\%. Não houve diferenças na composição química das carnes de aves em relação aos sistemas de produção.
\end{abstract}

Palavras-chave: Qualidade da carne de peru. Ventilação na produção de perus. Sistemas de ventilação. Meleagris gallopavo.

Correspondence to:

Karina Ramirez Starikoff

Universidade Federal da Fronteira Sul

Av. Fernando Machado, 108E

CEP 89814-470, Chapecó, SC, Brazil

e-mail: karina.starikoff@uffs.edu.br

Received: 22/01/2018

Approved: 07/08/2018

\section{Introduction}

The poultry industry in Brazil has grown significantly in recent years, generating employment for two million people in different activities of the production cycle, moving around 10 billion dollars a year and representing approximately $2 \%$ of the gross domestic product (MENDES, SALDANHA, 2004; UBA, 2014). Turkey breeding produces more than 30 million birds a year, representing 3.5\% of Brazilian poultry production (UBA, 2006).

New technologies and sanitary control stimulated the increase in the sector, particularly for farmers to diversify production and increase profit in small areas (MENDES et al., 2010). 
Turkey meat is lean compared with red meat. Both are essential components of diets in developed countries, especially for their sensory characteristics, such as taste and texture. In addition, because of its high nutritional value, turkey is a source of animal protein, minerals and vitamins (LOPES, 2009).

One of the greatest challenges for the meat industry is to offer soft, juicy products, presenting pleasant color and flavor (DIRINCK et al., 1996). According to Gaya and Ferraz (2006), the main attributes evaluated to determine meat quality are color, water-holding capacity and texture.

The barn ventilation system is important to reduce thermal stress and, consequently, avoid losses in meat quality. Poultry at high temperatures spend less time feeding to decrease the energy consumed in digestion. There is also an increase in poultry consumption of water, responsible for cooling the body. Because of this and also due to age, the older the birds experiencing thermal stress, the lower their weight gain will be (SEVEGNANI et al., 2005).

Baêta (1998) says that Brazilian aviaries can be classified as opened (traditional system of ventilation) and closed (mechanical exhausted ventilation). Opened aviaries are simpler and have considerable porosity, even when the blinds are closed. Indoors aviaries are more complex, very expensive, and require forced ventilation and evaporative cooling.

Considering the lack of information for the evaluation of turkey meat quality according to breeding, this investigation evaluated the chemical composition and quality of turkey meat raised in two kinds of production systems: barns with traditional mechanical ventilation and barns with mechanical exhausted ventilation systems.

\section{Materials and Methods}

One hundred samples of turkey meat obtained from birds reared in a traditional ventilation aviary and one hundred samples of turkey meat obtained from birds reared in a mechanical exhausted ventilation aviary were compared. Each sample consisted of $500 \mathrm{~g}$ turkey breast, from male birds, which were obtained after slaughter and frozen at $15^{\circ} \mathrm{C}$ for 30 days. The analyses were for water loss for cooking, water loss for dripping, texture (shear force), $\mathrm{pH}$, color, moisture, ash, lipids and proteins.

\section{Meat Quality and Nutrional Composition}

Water loss for cooking was measured following the methodology proposed by Garcia et al. (2005) and Costa et al. (2002), with some adjustments in cooking temperatures and material used to package the contents. Samples of approximately $50 \mathrm{~g}$ were weighed in a semi-analytical Shimadzu balance, Model AUY220, placed in a beaker, covered with aluminum foil, and boiled in water bath at $80^{\circ} \mathrm{C}$ for one $\mathrm{h}$. They were then placed on absorbent paper to reach room temperature and weighed again. The difference between the weights was calculated and converted into percentage.

For the water loss for dripping analysis, $10 \mathrm{~g}$ of the sample were used, which were weighed in a semianalytical balance, kept in a cooling chamber at $4^{\circ} \mathrm{C}$ for $48 \mathrm{~h}$ and weighed again. The water loss percentage from the difference between the initial and final weight (ATHAYDE et al., 2012) was calculated.

The texture analysis (shear strength) used the same samples as those for analyzing water loss for cooking. After baking, the samples were cut into rectangles of 1 x $1 \times 2 \mathrm{~cm}$ diameter, in duplicate, and subjected to shear in TAXT2 texturometer equipped with WarnerBratzler meat cell, SMS standard (Stable Micro System) with $50 \mathrm{~kg}$ force capacity $(500 \mathrm{~N})$. The result was obtained from the average of the duplicates (KERTH et al., 1995; HEINEMANN et al., 2003; ATHAYDE et al., 2012).

Ten grams of sample were weighed and placed in a $250 \mathrm{ml}$ beaker, homogenized with $100 \mathrm{ml}$ of doubly distilled water for $1 \mathrm{~min}$, allowed to stand for $30 \mathrm{~min}$ and then subjected to reading digital benchtop $\mathrm{pH}$ meter, Lucadema, model LUCA - 210P (TERRA; BRUM, 1988). 
Color was measured by portable colorimeter for food, Konica Minolta Chroma Meter CR-400. After the 30 min standard period of exposure to atmospheric air, the colorimeter was applied directly into the muscle to measure the color. (GARCIA et al., 2005; MAGANHINI et al., 2007). The system employed was the CIELAB, based on three components: luminance, represented by $L^{*}$, ranging from 0 (black) to 100 (white); tone was represented by $\mathrm{a}^{*} ;-\mathrm{a}^{*}$ is the ratio of the colors red and green; and $b^{*},-b^{*}$ is the ratio between the yellow and blue colors (BARROS et al., 2014).

Moisture was determined by the gravimetric method at $105^{\circ} \mathrm{C}$. It was measured as the difference between initial and final weight and expressed as a percentage (MORETTO, 2008).

For mineral material calculation, the same samples were used, but they were incinerated in a muffle furnace at $550^{\circ} \mathrm{C}$, destroying the organic matter, without decomposing the mineral residue constituents, until the ashes acquire white coloring. After subsequent weighing, we calculated the value of sample percentage (TERRA; BRUM, 1988).

Protein was determined in three stages: digestion, distillation and titration. Sample $0.5 \mathrm{~g}$ was transferred into a Kjeldahl tube, with $2 \mathrm{~g}$ of catalyser and $5 \mathrm{ml}$ of sulfuric acid. It was heated for 4 to $6 \mathrm{~h}$ until the liquid looks transparent. After this process, $20 \mathrm{ml}$ of distilled water were added and it was connected to the distillation system; sodium hydroxide $50 \%$ was further added until a blue coloration indicated alkalinity. Lastly, the distillate received $5 \mathrm{ml}$ of boric acid to $4 \%$ and titrated with a $0.1 \mathrm{NHCl}$ solution, employing the conversion factor (6.25) and methodology proposed by Moretto (2008).

The carbohydrates analysis followed the Nifext method (PEDROSA; COZZOLINO, 2001). The lipid analysis followed the Bligh-Dyer method (1959).

\section{Statistical Analysis}

The unit values in growth performance, evaluation of meat quality and nutritional composition were tabulated in spreadsheets for calculating the average per lot and then by the raising system.

The system averages were subjected to variance analysis, using Tukey's test, by Sisvar program for Windows 5.3 Build 77.

\section{Results and Discussion}

\section{Meat Quality}

The average results of the breast meat quality of turkeys raised in the air traditional system and in the air exhausted system are shown in Table 1.

The average of the flocks was subjected to statistical analysis using Tukey's test, which showed significant difference $(\mathrm{p}<0.05)$ only in water loss for dripping (WLD). The results obtained in the present paper, was higher than the value found by Bridi et al. (2012), who found 3.81\% in chicken meat, and Woelfel et al. (2002), who found $3.32 \%$, also in chickens. The high rates of WLD can be justified by differences in methodology. This research was decided by the absence of packaging the pieces of meat subjected to drip under refrigeration (ATHAYDE et al., 2012), whereas in other studies the prior packaging of parts was performed.

The average $\mathrm{pH}$ values found in this study, measured after 1-month freezing, were equal in both systems and very similar to the value of 5.94 found by Mckee et al. (1998), who carried out measurements on the day following slaughter. They were lower than those reported by Lopes (2009), which determined $\mathrm{pH}$ of 6.24 , but the meat measurement was carried out after 3-month freezing time. Both surveys were conducted on turkey breast meat. However, the difference from Lopes (2009) may be justified because of the time difference between slaughter and measurement. The freezing and thawing processes may also have influenced results. When compared to chicken breast, the value was similar to that found by Wattanachant et al. (2004), who obtained $\mathrm{pH}$ of 5.93.

The water loss for cooking values was higher than those in Mckee et al. (1998) and Costa (2006), which determined $26.58 \%$ and $28.38 \%$, respectively, in turkey breast. Water retention regards the appearance of the 
meat before and during cooking, and concerns softness (PALEZI et al., 2014).

Meat texture is related to the amount of intramuscular water and meat water retention capacity, so that the higher the water content in the muscle, the greater the meat tenderness (ANADÓN,
2002). Costa (2006), found $61.23 \mathrm{kgf}$ in turkeys, almost double that found in our research, which was closer to the result of $2.27 \mathrm{kgf}$ in turkeys in Lopes (2009), similar to the $2.36 \mathrm{kgf}$ found by Oba et al. (2007), but in chickens.

Table 1 - Breast meat quality parameters of turkeys raised in traditional ventilation system (TS) or in an exhausted air system (ES) - Realeza/Paraná, Brazil - 2016

\begin{tabular}{|c|c|c|c|c|c|c|c|}
\hline $\begin{array}{c}\text { Lots/ } \\
\text { Systems }\end{array}$ & $\mathrm{pH}$ & WLD (\%) & WLC (\%) & $\mathrm{T}(\mathrm{kgf})$ & $C\left(L^{*}\right)$ & $C\left(a^{*}\right)$ & $C\left(b^{*}\right)$ \\
\hline 1 & 5.90 & 11.18 & 33.37 & 3.67 & 51.33 & 4.38 & 6.87 \\
\hline 2 & 5.79 & 12.39 & 30.89 & 3.68 & 51.17 & 4.20 & 6.92 \\
\hline 3 & 6.07 & 11.72 & 30.80 & 3.28 & 47.80 & 3.90 & 6.18 \\
\hline 4 & 6.08 & 14.47 & 30.54 & 4.35 & 47.91 & 4.00 & 6.01 \\
\hline 5 & 5.99 & 21.53 & 33.45 & 4.07 & 47.81 & 4.54 & 6.84 \\
\hline Average TS & 5.97 & $14.26^{\star *}$ & 31.81 & 3.81 & 49.20 & 4.21 & 6.56 \\
\hline $\begin{array}{l}\text { Standard } \\
\text { deviation }\end{array}$ & 0.12 & 4.25 & 1.47 & 4.04 & 1.87 & 0.26 & 0.43 \\
\hline 1 & 5.78 & 24.86 & 32.00 & 3.75 & 51.74 & 5.17 & 7.47 \\
\hline 2 & 5.85 & 10.88 & 29.70 & 3.76 & 52.10 & 4.14 & 7.14 \\
\hline 3 & 5.94 & 20.98 & 29.93 & 3.67 & 47.77 & 4.69 & 7.20 \\
\hline 4 & 6.01 & 19.71 & 31.21 & 3.98 & 46.84 & 3.53 & 6.07 \\
\hline 5 & 6.27 & 19.60 & 29.89 & 3.99 & 45.75 & 4.20 & 6.56 \\
\hline Average ES & 5.97 & $19.21^{\star *}$ & 30.55 & 3.83 & 48.84 & 4.34 & 6.89 \\
\hline Standard deviation & 0.19 & 5.12 & 1.01 & 1.43 & 2.9 & 0.62 & 0.56 \\
\hline
\end{tabular}

Table 2 - Nutritional composition of breast meat from turkeys raised in a traditional ventilation system (TS) or in an exhausted air system (ES) - Realeza/Paraná, Brazil - 2016

\begin{tabular}{cccccc}
\hline $\begin{array}{c}\text { Lots/ } \\
\text { Systems }\end{array}$ & Moisture (\%) & Protein (\%) & Carbohydrates (\%) & $\begin{array}{c}\text { Mineral } \\
\text { Matter (\%) }\end{array}$ & Lipids (\%) \\
\hline 1 & 75.82 & 23.63 & 0.00 & 1.24 & 0.33 \\
2 & 66.67 & 23.18 & 0.58 & 1.15 & 0.84 \\
3 & 62.62 & 24.10 & 11.60 & 1.21 & 0.83 \\
4 & 68.73 & 24.55 & 5.00 & 1.28 & 0.81 \\
5 & 68.29 & 24.47 & 3.82 & 1.23 & 1.67 \\
Average TS & 68.43 & 23.98 & 4.20 & 1.22 & 0.89 \\
Standard & 5.23 & 0.58 & 0.03 & 4.65 & 0.47 \\
deviation & 73.77 & 23.15 & 2.05 & 1.27 & 0.39 \\
1 & 74.70 & 22.72 & 0.06 & 1.26 & 1.31 \\
2 & 60.25 & 24.47 & 13.91 & 1.23 & 0.72 \\
3 & 62.68 & 24.02 & 11.33 & 1.16 & 1.00 \\
4 & 70.65 & 25.49 & 2.29 & 1.32 & 0.42 \\
5 & 68.41 & 23.97 & 5.93 & 1.24 & 0.77 \\
Average ES & 6.57 & 1.09 & 0.04 & 6.24 & 0.39 \\
Standard & & & & & \\
deviation & & & & & \\
\hline
\end{tabular}


The color observed on the meat surface is the result of the absorption of light by myoglobin and other components, such as muscle fibers and its protein, also being influenced by amount of free liquid present in meat (OLIVO; SHIMOKOMAKI, 2006). The determination is made by the measurement of three variables: $L^{*}, a^{*}$ and $b$. The $L^{*}$ values found, which represent the luminosity, were higher in Lopes (2009), which was 40.74 . Such values, 49.20 and 48.84 , are characterized as a trend towards dark. When $\mathrm{a}^{*}$ is observed, the 4.21 and 4.34 values are characterized by a reddish trend, and were lower than Lopes (2009), who found 6.47. For variable $b^{*}$, the values found of 6.56 and 6.89 are characterized like trends to yellow, and the values were higher than Lopes (2009), who found -0.71 . However, the brightness and trend in yellow values were closer to those found by Garcia et al. (2005), which evaluated chicken breast and obtained the following results: $L^{*} 49.99 ; a^{*} 1.28 ; b^{*}$ 7.98 .

\section{Nutritional Composition}

The results of nutritional composition between animals raised in traditional system and in mechanical ventilation system presented no significant statistical difference. The arithmetic average of turkey breast meat for traditional and mechanical ventilation system is shown in Table 2.

The turkey breast moisture was lower than that of chicken breast; Garcia et al. (2005) observed $71.88 \%$ in chickens. The same authors found similar to protein

\section{References}

ANADÓN, H. L. S. Biological, nutritional and processing factors affecting breast meat quality of broilers. 2002. $181 \mathrm{f}$. Thesis (Doctor of Philosophy in Animal and Poultry Science)-Faculty of Virginia Polytechnic Institute and State University, Blacksburg, Virginia, 2002.

ATHAYDE, N. B.; DALLA COSTA, O. A.; ROÇA, R. O.; GUIDONI, A. L.; LUDTKE, C. B.; LIMA, G. J. M. M. Meat quality of swine supplemented with ractopamine under values $(23.83 \%)$ and mineral matter $(1.23 \%)$; Oba et al. (2007) found $1.20 \%$ in chickens.

The lipid values found in the present research were larger than the $0.48 \%$ in turkey breast found by Lopes (2009). When compared to chicken breast, the values are greater than in Wattanachant et al. (2004), who found $0.68 \%$, but are lower than in Oba et al. (2007), who found $1.53 \%$ fat in chickens.

\section{Conclusion}

Barn ventilation is an important factor that contributes to maintaining turkeys in a thermal comfort zone, which is directly related to the yield of these birds that could affect their productivity levels.

The ventilation with the air exhausted system has satisfactory results in chickens. However, the results of the present investigation showed that in the examined samples, there was no significant difference $(p>0.05)$ found in the following parameters evaluated in the turkey meat quality: loss of water by cooking, texture (shear strength), $\mathrm{pH}$ and color, only loss of dripping water, although the results may have been influenced by the method used.

The results for the nutritional production of moisture, protein, ash and lipids also did not present any significant difference ( $\mathrm{p}>0.05)$.

Thus, from the results found in this research, we concluded that there are no differences in the quality and nutritional composition of turkey meat according to the kind of ventilation system used in the raising barns.

commercial conditions in Brazil. Journal of Animal Science, v. 90, n. 12, p. 4604-4610, 2012. doi: 10.2527/jas.2012-5102.

BAÊTA, F. C. Sistemas de ventilação natural e artificial na criação de aves. In: SIMPÓSIO INTERNACIONAL SOBRE AMBIÊNCIA E SISTEMAS DE PRODUÇÃO AGRÍCOLA, 1998, Campinas. Anais... Concórdia: EMBRAPA- CNPSA, 1998. p. 96-117. 
BARROS, S. V. S.; MUNIZ, G. I. B.; MATOS, J. L. M. Caracterização colorimétrica das madeiras de três espécies florestais da Amazônia. CERNE, v. 20, n. 3, p. 337-342, 2014. doi: 10.1590/01047760201420031421.

BLIGH, E. G.; DYER, W. J. A rapid method of total lipid extraction and purification. Canadian Journal of Biochemistry and Physiology, v. 37, n. 8, p. 911-917, 1959. doi: 10.1139/o59-099.

BRIDI, A. M.; FONSECA, N. A. N.; SILVA, C. A.; BALARIN, M. R. S.; FLAIBAN, K. K. M. C.; CONSTANTINO, C.; TARSITANO, M. A.; CARDOSO, T. A. B. Indicadores de estresse e qualidade da carne em frangos abatidos pelo método "Halal". Semina: Ciências Agrárias, v. 33, n. 6, p. 2451-2460, 2012. doi: 10.5433/1679-0359.2012v33n6p2451.

COSTA, E. C.; RESTLE, J.; BRONDANI, I. L.; PEROTTONI, J.; FATURI, C.; MENEZES, L. F. G. Composição física da carcaça, qualidade da carne e conteúdo de colesterol no músculo Longissimus dorsi de novilhos red angus superprecoces, terminados em confinamento e abatidos com diferentes pesos. Revista Brasileira de Zootecnia, v. 31, n. 1, p. 417-428, 2002. doi: 10.1590/S1516-35982002000200017.

COSTA, F. Caracterização do processo de Rigor Mortis e da maciez dos músculos Gastrocnemius e Pectoralis e efeito da radiação gama na vida comercial da carne de peru (Meleagris gallopavo). 2006. 137 f. Tese (Doutorado em Higiene Veterinária e Processamento Tecnológico de Produtos de Origem Animal)-Universidade Federal Fluminense, Niterói, Rio de Janeiro, 2006.

DIRINCK, P.; WINNE, A.; CASTEELS, M.; FRIGG, M. Studies on vitamin E and meat quality. 1.Effect of feeding high vitamin E levels on time-related pork quality. Journal of Agricultural and Food Chemistry, v. 44, n. 1, p. 65-68, 1996. doi: 10.1021/jf940607x.

GARCIA, R. G.; MENDES, A. A.; COSTA, C.; PAZ, I .C. L. A.; TAKAHASHI, S. E.; PELÍCIA, K. P.; KOMIYAMA, C. M.; QUINTEIRO, R. R. Desempenho e qualidade da carne de frangos de corte alimentados com diferentes níveis de sorgo em substituição ao milho. Arquivo Brasileiro de Medicina Veterinária e Zootecnia, v. 57, n. 5, p. 634-643, 2005. doi: 10.1590/S0102-09352005000500009.

GAYA, L. G.; FERRAZ, J. B. S. Aspectos genéticoquantitativos da qualidade da carne em frangos. Ciência Rural, v. 36 , n. $1, \quad$ p. 349-356, 2006 . doi: 10.1590/S010384782006000100058.

HEINEMANN, R. J. B.; PINTO, M. F.; ROMANELLI, P. F. Fatores que influenciam a textura da carne de novilhos Nelore e cruzados Limousin-Nelore. Pesquisa Agrope- cuária Brasileira, v. 38, n. 8, p. 963-971, 2003. doi: 10.1590/S0100-204X2003000800009.

KERTH, C. R.; MILLER, M. F.; RAMSEY, C. B. Improvement of beef tenderness and quality traits with calcium chloride injection in beef loins 48 hours postmortem. Journal of Animal Science, v. 73, n. 3, p. 750756, 1995. doi: 10.2527/1995.733750x.

LOPES, A. F. V. Efeito do sistema de produção e do sexo na qualidade da carne de peru. 2009. 83 f. Dissertação (Mestrado em Produção Animal)-Instituto Superior de Agronomia, Universidade Técnica de Lisboa, Lisboa, 2009.

MAGANHINI, M. B.; MARIANO, B.; SOARES, A. L.; GUARNIERI, P. D.; SHIMOKOMAKI, M.; IDA, E. I. Carnes PSE (Pale, Soft, Exudative) e DFD (Dark, Firm, Dry) em lombo suíno numa linha de abate industrial. Ciência e Tecnologia de Alimentos, v. 27, p. 69-72, 2007. Supplement 1. doi: 10.1590/S0101-20612007000500012.

MCKEE, S. R.; HARGIS, B. M.; SAMS, A. R. Pale, soft, and exudative meat in turkeys treated with succinylcholine. Poultry Science, v. 77, n. 2, p. 356-360, 1998. doi: 10.1093/ps/77.2.356.

MENDES, A. A.; SALDANHA, E. S. P. B. Produção de frangos de corte. In: MENDES, A. A.; NÄÄS, I. A.; MACARI, M. (Eds.). A cadeia produtiva de carne de aves no Brasil. Campinas: FACTA, 2004. p. 1-22.

MENDES, A. S.; MOURA, D. J.; NÄÄS, I. A.; SONODA, L. T. Temperaturas de acionamento de sistemas de climatização para perus em épocas de baixa umidade relativa do ar. Engenharia Agrícola, v. 30, n. 5, p. 788-798, 2010. doi: 10.1590/S0100-69162010000500002.

MORETTO, E. Introdução à ciência de alimentos. 2 ed. Florianópolis: Editora da UFSC, 2008. 237 p.

OBA, A.; SOUZA, P. A.; SOUZA, H. B. A.; LEONEL, F. R.; PELICANO, E. R. L.; ZEOULA, N. M. B.; BOLELLI, I. C. Qualidade da carne de frangos de corte submetidos a dietas suplementadas com crômio, criados em diferentes temperaturas ambientais. Acta Scientiarum: Animal Sciences, v. 29, n. 2, p. 143-149, 2007. doi: 10.4025/actascianimsci.v29i2.218.

OLIVO, R.; SHIMOKOMAKI, M. Carne PSE. In: SHIMOKOMAKI, M.; OLIVO, R.; TERRA, N. N.; FRANCO, B. D. G. M. (Eds.). Atualidades em ciência e tecnologia de carnes. São Paulo: Varella, 2006. p. 85-103.

PALEZI, S. C.; CARLI, E.; SILVA, G. P. R.; ZEN, P. Utilização de diferentes hidrocolóides para melhorar a 
qualidade sensorial de produtos Cárneos. Unoesc \& Ciência - ACET, v. 5, n. 2, p. 129-134, 2014.

PEDROSA, L. F. C.; COZZOLINO, S. M. F. Composição centesimal e de minerais de mariscos crus e cozidos na cidade de Natal/RN. Ciência e Tecnologia de Alimentos, v. 21 , n. 2, p. 154-157, 2001. doi: 10.1590/S010120612001000200006.

SEVEGNANI, K. B.; CARO, I. W.; PANDORFI, H.; SILVA, I. J. O.; MOURA, D. J. Zootecnia de precisão: análise de imagens no estudo do comportamento de frangos de corte em estresse térmico. Revista Brasileira de Engenharia Agrícola e Ambiental, v. 9, n. 1, p. 115-119, 2005. doi: 10.1590/S1415-43662005000100017.

TERRA, N. N.; BRUM, M. A. R. Carne e seus derivados: técnicas de controle de qualidade. São Paulo: Nobel, 1988. $121 \mathrm{p}$.
UNIÃO BRASILEIRA DE AVICULTURA (UBA). Relatório Anual. São Paulo: Associação Brasileira de Proteína Animal, 2006.

UNIÃO BRASILEIRA DE AVICULTURA (UBA). Relatório Anual. São Paulo: Associação Brasileira de Proteína Animal, 2014.

WATTANACHANT, S.; BENJAKUL, S.; LEDWARD, D. A. Composition, color, and texture of Thai indigenous and broiler chicken muscles. Poultry Science, v. 83, n. 1, p. 123128, 2004. doi: 10.1093/ps/83.1.123.

WOELFEL, R. L.; OWENS, C. M.; HIRSCHLER, E. M.; MARTINEZ-DAWSON, R.; SAMS, A. R. The characterization and incidence of pale, soft, and exudative broiler meat in a commercial processing plant. Poultry Science, v. $81, \quad$ n. $4, \quad$ p. 579-584, 2002. doi: $10.1093 / \mathrm{ps} / 81.4 .579$. 